\title{
Widely distributed breeding populations of Canada warbler (Cardellina canadensis) converge on migration through Central America
}

\author{
A. Roberto-Charron ${ }^{*}$ (D) J. Kennedy ${ }^{2}$, L. Reitsma ${ }^{3}$, J. A. Tremblay ${ }^{4,5}$, R. Krikun ${ }^{6}$, K. A. Hobson${ }^{7}$, J. Ibarzabal ${ }^{5}$ and
} K. C. Fraser ${ }^{1}$

\begin{abstract}
Background: To effectively conserve migratory species, the entire range encompassed by their annual life cycle needs to be considered. Most research on Nearctic-Neotropical migratory birds has focused on the breeding grounds resulting in a general lack of knowledge regarding the wintering and migratory periods. The Canada Warbler (Cardellina canadensis) has declined by 71\% from 1970 to 2012, at a rate of 2.9\% per year, and is listed as Threatened in Canada. As with most Nearctic-Neotropical migrants, conservation efforts outside the breeding range are limited by a poor understanding of migration routes and the connectivity between specific breeding and wintering populations.

Results: To determine migratory routes of multiple breeding populations of Canada Warblers, we directly-tracked individuals using light-level geolocators deployed at four sites across the breeding range, spanning approximately 43 degrees in longitude (Alberta, Manitoba and Québec, Canada, and New Hampshire, USA). Twenty-five geolocators with usable data were recovered from three sites and were analyzed using FlightR to determine fall migration routes $(n=18)$ and individual wintering sites $(n=25)$. Individuals from all breeding populations took a western fall migration route at the Gulf of Mexico; with $77.8 \%$ of birds funnelling into a narrow geographic space along the western side of the Gulf of Mexico $\left(97^{\circ} \mathrm{W}-99^{\circ} \mathrm{W}\right)$. We found no evidence for population-specific, parallel migration routes. Most individuals (72\%) overwintered in Colombia. The remaining individuals overwintered in Venezuela.

Conclusions: Our results demonstrate convergence of migratory routes around a migration barrier for individuals originating from widely distributed breeding areas. Further, we suggest the potential importance of habitat around the Gulf of Mexico during migration and Andean forest in Colombia as overwintering habitat for this threatened species. Future research should be directed at understanding how these areas are used by Canada Warblers.
\end{abstract}

Keywords: Migration, Geolocators, Songbird, Nearctic-Neotropical migratory birds, Canada warbler, Cardellina canadensis, Gulf of Mexico, Conservation

\footnotetext{
* Correspondence: arobertocharron@gmail.com

'Department of Biological Sciences, University of Manitoba, Winnipeg, Manitoba, Canada

Full list of author information is available at the end of the article
}

(c) The Author(s). 2020 Open Access This article is licensed under a Creative Commons Attribution 4.0 International License, which permits use, sharing, adaptation, distribution and reproduction in any medium or format, as long as you give appropriate credit to the original author(s) and the source, provide a link to the Creative Commons licence, and indicate if changes were made. The images or other third party material in this article are included in the article's Creative Commons licence, unless indicated otherwise in a credit line to the material. If material is not included in the article's Creative Commons licence and your intended use is not permitted by statutory regulation or exceeds the permitted use, you will need to obtain permission directly from the copyright holder. To view a copy of this licence, visit http://creativecommons.org/licenses/by/4.0/ The Creative Commons Public Domain Dedication waiver (http://creativecommons.org/publicdomain/zero/1.0/) applies to the data made available in this article, unless otherwise stated in a credit line to the data. 


\section{Background}

More than half of the birds that breed in North America are migratory, and many are experiencing rapid population declines [1-3]. From 1970 to 2017, an estimated 2.5 billion individuals of migratory bird species have been lost in North America alone [4]. Long-distance migrants are particularly at risk, with steeper declines than their short-distance counterparts [5]. Most research on migratory species has been focused on the breeding grounds with migration being the least understood portion of the annual cycle [6]. Recent technological innovations now allow for year-round tracking of migratory songbirds by using archival light-level geolocators [7-9]. These units record time of day and light-level data which together can provide locations for each day that the unit is on the bird. These units are now small enough to be able to track small songbird migrants (less than $10 \mathrm{~g}$ ), including warblers [8-11]. Tracking species-at-risk year-round can yield new insight into the migratory and overwintering ecology of the species, providing invaluable information to effectively manage declining populations and determine conservation priorities $[7,9,12-14]$.

The Canada Warbler (Cardellina canadensis) is a long-distance Nearctic-Neotropical migrant, and a speciesat-risk listed as Threatened in Canada, where approximately 3 million individuals or $75 \%$ of the global population breeds [15]. The Canada Warbler breeds across the boreal forest in Canada and in the northeastern United States $[15,16]$ and overwinters in northwestern South America from the Amazon Basin into the Andean foothills of Venezuela, Ecuador, Colombia, Panama, and Peru [17]. Based on long-term Breeding Bird Survey data, this species has experienced a population loss of $71 \%$ from 1970 to 2012 [18], declining range-wide at a mean rate of $2.05 \%$ per year from 1966 to 2015 (95\% CI [-1.3, - 2.8] [3];). Over this period, the annual population trend was $-2.82 \%$ in Alberta (95\% CI $[-6.03,0.00]),-0.44 \%$ in Manitoba (95\% CI $[-2.70,1.81]),-3.02 \%$ in Québec (95\% CI $[-4.76,-1.22])$ and $-5.2 \%$ in New Hampshire (95\% CI $[-6.53,-3.84])$ [3]. The cause of these population declines and factors contributing to the varying rates of decline across the range are unknown [15]. These may be driven by factors at any point in the annual cycle, including the little-studied migration and overwintering periods [19]. Most existing research on Canada Warblers to date has been focused at the breeding grounds (see [20-24]), and knowledge of migratory and overwintering ecology is limited due to the low recovery rates of banded birds $(0.19 \%$ or 188 of the 98,967 Canada Warblers banded in Canada and the United States from 1960 to 2015 [25]; Supplemental Figure 1), leaving a significant knowledge gap in our understanding of migratory routes and connectivity.
Despite the low recovery rates of banded birds, generally, Canada Warblers are thought to migrate from their breeding grounds through Central America to South America, avoiding any major water crossings (i.e., the Gulf of Mexico) [17, 18, 26] (see also Supplemental Figure 1). This migration route has been substantiated by numerous reports of Canada Warblers migrating over Central America [27-32] (see also Supplemental Table S1). Canada Warblers encountered in the Caribbean and Atlantic during the migratory period have been classified as vagrants (Table S1), as these individuals were observed outside of their known range. Migration routes over the Caribbean have been deemed unlikely, owing to the perceived infrequence in these observations, as well as other evidence in support of overland migratory routes [33-35]. However, some species of small songbirds migrate between North and South America using a trans-Atlantic migration routes $[8,10]$. There are 57 records of Canada Warblers on eBird for the Caribbean Islands dating from 1990 to 2016, 51 of which (89\%) were observed in the fall, and 46 (80\%) observed in Bermuda ([36], accessed February 2016). Additionally, there are numerous published records of Canada Warblers in the Caribbean and Atlantic during the fall migration period (Table S1), leaving open the question of the potential for trans-Atlantic migration paths of some individuals.

Several migratory songbirds exhibit population-specific migration routes and wintering sites (termed strong migratory connectivity) [36], emphasizing the importance of investigating patterns in annual movements of individuals and populations. Population-specific migration routes and wintering sites, such as parallel migration patterns, whereby birds from the western limit of the breeding range migrate to and overwinter in the western portion of the range and eastern birds to the east, minimizes the distance travelled during migration, reducing the energetic costs [37]. Such patterns have been documented in several songbird species [38-40]. Furthermore, isotopic research on Canada Warblers in the wintering grounds connotes strong migratory connectivity between breeding areas and overwintering sites in the Colombian Andes and suggests the potential for parallel migration patterns, as individuals that overwintered in the eastern cordilleras originated from the eastern breeding range, and individuals from the western cordilleras originated from the west [41]. The presence of strong migratory connectivity may be reflected in disparate population trends across the breeding grounds [3], due to variable levels of threats and risks associated with different routes [42] and overwintering sites [39] for different populations. It follows that development of effective conservation strategies may require population-specific approaches for species exhibiting strong migratory connectivity, and further highlights the need to substantiate the migration route(s) of the Canada Warbler. 
Here, we used light-level geolocators to delineate the fall migration routes of Canada Warblers originating from four different breeding populations across their range in North America. We predicted that Canada Warblers will exhibit population-specific migration routes with a parallel migration strategy (i.e., birds originating from the western extent of the breeding range will use overwintering sites in the western extent of the overwintering range, and birds breeding in eastern North America are most likely to exhibit a trans-Atlantic migration path to eastern extent of the overwintering range). To characterize migration strategy, we sought to: 1) identify the degree of variation in fall migration routes of Canada Warblers from different populations; and, 2) identify their overwintering areas.

\section{Methods}

\section{Field methods}

We deployed 40 geolocators in Alberta in 2014 and an additional 114 geolocators across the breeding range in 2015 (Table 2). To increase the probability of successful data collection and recovery, we deployed three different types of geolocator models: Migrate Technology Ltd. models W30Z11-DIP, W50Z11-DIP, and Biotrack model P30Z11-7-DIP (referred to as W30, W50 and P30 respectively hereafter). These geolocator units vary in mass, size and battery life (Table 1), but all weighed less than $5 \%$ of the bird's total body mass including harnesses, as suggested by Fair et al. [43]. To deploy the units, we used a modified Rappole and Tipton [44] legloop harness made of polypropylene thread or Stretch Magic (Table 1). We individually fitted the polypropylene thread harnesses to birds, whereas we prefabricated the harnesses made with Stretch Magic as recommended by Streby et al. [45] using an allometric function to appropriately size them [46].

In June of 2014 and 2015, using mist nets $(30 \mathrm{~mm}$ mesh; $6 \mathrm{~m} \times 3 \mathrm{~m}$ ) and a song lure, we captured second year (SY) and after-second year (ASY) male Canada Warblers on their breeding territories at four different sites: Lesser Slave Lake Provincial Park, Alberta (55.436 $\left.\mathrm{N}, 114.829^{\circ} \mathrm{W}\right)$, Whiteshell Provincial Park, Manitoba $\left(49.917^{\circ} \mathrm{N}, 95.333^{\circ} \mathrm{W}\right)$, Canaan, New Hampshire $\left(43.676^{\circ} \mathrm{N}, 72.055^{\circ} \mathrm{W}\right)$ and Forêt d'Enseignement et de Recherche Simoncouche (FERS), Université du Québec in Chicoutimi (UQAC), Québec $\left(48.210^{\circ} \mathrm{N}, 71.245^{\circ} \mathrm{W}\right)$. Capture locations were recorded using a hand-held GPS unit (GPSMAP 64, NAD 83). Once captured, we aged males using feather characteristics [47], took standard morphometric measurements and banded each bird with a federally issued aluminum leg band and up to two color bands for later visual re-identification. In the year following deployment, we searched for birds with geolocators within a $500 \mathrm{~m}$ radius of the 2014 and 2015 deployment sites $[39,48]$. We used the same method for recapture as was used for initial capture.

\section{Geolocator and statistical analysis}

Light-level geolocation approximates geographic coordinates based on light levels and time recorded by the unit [49]. As outlined by Lisovski et al. [50], the process of geolocator analysis involves four main steps: 1) identifying twilights, 2) calibration, 3) preliminary location estimates, and 4) refinement of locations. To analyze our geolocator data, we followed methods outlined by Rakhimberdiev et al. [51] and Lisovski et al. [50].

We identified twilight times using the 'threshold method' [52] of the 'BAStag' Package [53] in R [54]. The 'threshold method' derives latitude from day length and longitude from the time of solar noon [50]. For a twilight event to be annotated using this method, the light intensity needs to cross a given threshold. We used a threshold level of 1.5 , as it was the lowest limit that excluded any interfering light pollution present at night in the geolocator data [50].

We calibrated data for the deployment location to account for device sensitivity and behavioural and habitat effects that can interfere with the light data. We used the period post geolocator deployment, when the individual was stationary on breeding territory, and subsequently

Table 1 Canada Warbler geolocator model information for units that were deployed in 2014 and 2015 for sites in Alberta, Manitoba, New Hampshire and Québec

\begin{tabular}{|c|c|c|c|}
\hline Model Type & W30Z11-DIP & W50Z11-DIP & P30Z11-7-DIP \\
\hline Weight & $0.30 \mathrm{~g}$ & $0.42 \mathrm{~g}$ & $0.36 \mathrm{~g}$ \\
\hline Approximate battery life & 7 months & 10 months & 7 months \\
\hline Light stalk present & No & No & Yes \\
\hline Geolocator make & Migrate Technology Ltd & Migrate Technology Ltd & Biotrack \\
\hline Mass with polypropylene harness & $0.320 \mathrm{~g}$ & $0.440 \mathrm{~g}$ & - \\
\hline Average percent of total body mass of unit with polypropylene harness & $3.1 \%$ & $4.2 \%$ & - \\
\hline Weight with Stretch Magic harness & $0.316 \mathrm{~g}$ & $0.421 \mathrm{~g}$ & $0.370 \mathrm{~g}$ \\
\hline Average percent of total body mass of unit with Stretch Magic harness & $3.0 \%$ & $4.1 \%$ & $3.7 \%$ \\
\hline
\end{tabular}


calculated simple location estimates using the package SGAT in R [50] to derive preliminary location estimates.

When day lengths are equal around the world (equinox), sunrise and sunset times become uninformative measures of latitude. As longitude is derived from the time of solar noon, it is reliable even during the fall equinox $[51,52,55]$. We visually compared the raw longitude values between sites by plotting the individual longitude coordinates for each bird and the average longitudinal coordinates per site, including one standard deviation over time for each. Focus was placed on comparing the longitudinal values, due to the overall robustness of the longitudinal coordinates, and owing to the interest in discerning differences in migration routes that would have varying longitudinal values. Given that the deployment locations spanned a large range of longitudinal values, and our prediction that these longitudinal extents would stay somewhat consistent for the entire lifecycle, this proved a useful test in assessing this predictions.

Location estimates were refined using the package 'FLightR' [56, 57] in $\mathrm{R}$ following methods outlined by Rakhimberdiev et al. [51] and Lisovski et al. [50]. FLightR uses a particle filter to derive locations from a twilight model, spatial mask, and movement model. FLightR yields a posterior probability distribution with a mean indicating the most probable path taken by the individual while providing credible intervals. A spatial mask was applied to reduce unrealistic locations. The mask restricted stationary locations to land (stationary locations had to be less than $100 \mathrm{~km}$ from land), however, no restrictions were made preventing travel over water. The movement model constrained location estimates by making short distance flights common and long-distance flights relatively rare (as is expected with a migratory songbird). Coordinates that showed erratic long-distance movements north or south occurring in rapid succession during the equinox were further constrained, as they were deemed unrealistic and are likely attributed to equinox error. For mapping, the migration route was inferred by linking successive daily locations. During the equinox when latitudinal coordinates were erratic, the migration route was inferred by averaging latitudinal values between two reliable locations and plotting them with the longitudinal coordinates. As FLightR is unable to delineate flight paths for highly shaded light data, individuals with poor quality light data were discarded from migration route results.

When the location estimates were available from FLightR, we took the average during the wintering period to identify the overwintering location. When FLightR was unable to provide reasonable results, overwintering locations were determined by using the method described by Kramer et al. [39]. This method involves creating joint likelihood surfaces, transforming them into utilization distributions, extracting coordinates, and averaging them over the wintering period. The product of the likelihood surfaces created by FLightR for 6 subsequent transitions (i.e. sunrise or sunset) was taken to create a joint likelihood surface with a pixel size $\sim 0.5^{\circ}$, which reflects the most likely location for the midpoint (the third transition). To transform the likelihood surfaces into utilization distributions, the likelihood of each given cell was divided by the sum of all cells within each surface. Coordinates were then extracted from the utilization distribution from the cell with the highest probability of utilization. These coordinates were assigned to the third transition. The locations over the wintering period were then averaged to provide a mean overwinter location and were reviewed in ArcMap [58].

We used Fisher's exact tests to validate our field methods and compare against return rates of traditional banding techniques. We compared the apparent return rates of birds with geolocators that were deployed at Lesser Slave Lake Provincial Park, Alberta, with apparent return rates of birds banded at the nearby Lesser Slave Lake Bird Observatory to relate geolocator recoveries with traditional field techniques. Although the capture method differed slightly, with birds at the Lesser Slave Lake Bird Observatory being passively caught in mistnets and the geolocator recoveries actively searched for, this comparison offered an assessment of possible geolocator effect.

We used a logistic regression to test the effect of varying factors on the return rates. We considered the effect of the different sites (Alberta, Manitoba, Québec or New Hampshire), geolocator types (W30, W50 or P30), harness types (polypropylene thread, or Stretch Magic), ages at deployment (after second year (ASY) and second year (SY)) and deployment year (2014 or 2015). Various models were created including differing combinations of predictor variables and were ranked and evaluated to identify the best and most parsimonious model. AICc was used to correct for small sample size. Models with a $\triangle$ AIC value of less than two were considered competitive, unless they varied by only one parameter and had similar log-likelihood values [59].

\section{Results}

We recovered 29 geolocators, with a recovery rate of 10\% in 2015 and 24\% in 2016 (Table 2). A fifth returning bird was re-sighted in Alberta in 2015 and two returning males were observed in New Hampshire in 2016, but we were not able to recapture these individuals to retrieve the units. In 2016, two birds were recaptured in Alberta without their units due to harness failure. 


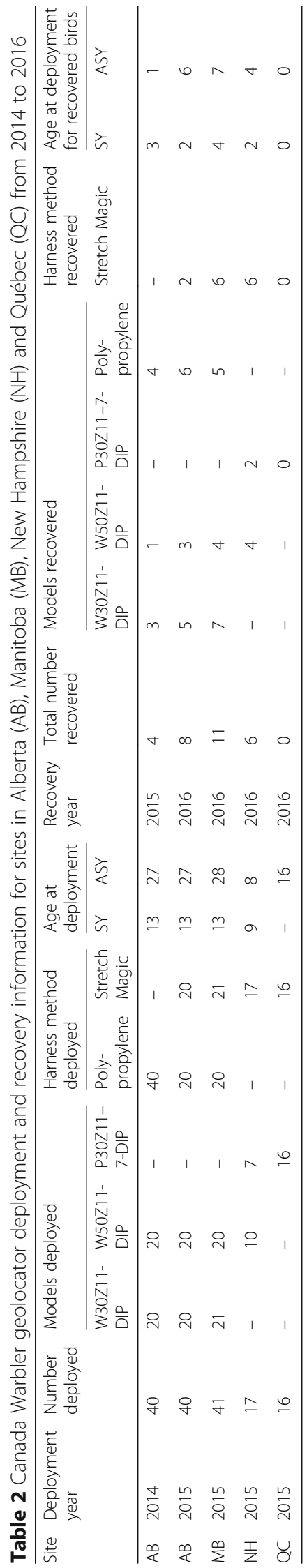


We found that return rates for birds recovered carrying geolocators in 2015 (4 out of 40;10\%) and 2016 (8 out of 40;20\%) did not significantly differ from return rates of banded birds in 2015 (4 out of 87; 4.6\%) and 2016 (3 out of 85; 3.5\%) at the Lesser Slave Lake Bird Observatory (Fisher's exact test, $P>0.995$ ). Logistic regression models were calculated to determine the effect of deployment site, geolocator type, harness type, deployment age and deployment year on the observed geolocator return rates and were compared through AICc (Table S2). Two models had a $\triangle$ AIC value of less than two, Model $6(\triangle \mathrm{AIC}=0.00)$ and $7(\Delta \mathrm{AIC}=1.388$; Supplemental Table S2). Model 6 included site and geolocator type as independent variables, whereas Model 7 included site alone. The log-likelihoods of both models were similar, indicating that the addition of geolocator type did little to improve the model performance.

Of the 29 retrieved units, 25 units successfully recorded light data to the wintering grounds and 18 units provided high quality data which were used to map fall migration routes for individuals from three breeding populations (Alberta, Manitoba, New Hampshire). One unit retrieved in New Hampshire provided a spring migration route. During fall migration, individuals from all breeding populations migrated south towards the Gulf of Mexico. Individuals either crossed or circumvented the Gulf of Mexico, and converged at a similar longitude in Central America (Fig. 1). The most probable migration path (or mean of all estimated locations) indicated that 7 of the 18 birds (38.9\%) travelled overland around the western side of the Gulf of Mexico, with 11 (61.1\%) partially crossing or flying across the Gulf of Mexico (Fig. 2). Seven individuals ( 3 from Alberta, 1 from Manitoba and 3 from New Hampshire), or 38.9\% of individuals tracked, crossed the Gulf of Mexico to the Yucatan Peninsula.

Most birds wintered in the northwestern portion of the wintering range (predominantly Colombia with a few overwintering in Venezuela), with no birds overwintering in the southern extent of the wintering range (Ecuador and Peru) or the easternmost extent of the wintering range (eastern Venezuela). Mean estimates of overwintering sites showed that 7 of the 25 birds overwintered in Venezuela, and the remaining 18 overwintered in Colombia (Fig. 3). Of the 10 Alberta birds that were tracked, 50\% overwintered in Venezuela, and 50\% overwintered in Colombia. Of the 9 birds recovered in Manitoba, 33.3\% overwintered in Venezuela with 66.6\% overwintering in Colombia. All 6 birds (100\%) from New Hampshire overwintered in Colombia. The average longitudes of individuals from the western-breeding Alberta population suggest they overwintered at higher more eastern longitudes (i.e. further east; average of approximately $69.5436^{\circ} \mathrm{W} \pm 0.4942^{\circ} \mathrm{SE}$ ), as compared to individuals from the eastern-breeding New Hampshire population (average of approximately $76.0900^{\circ} \mathrm{W} \pm 0.2536^{\circ} \mathrm{SE}$ ), with the centrally breeding Manitoba birds falling largely in the middle (average of approximately $73.2624^{\circ} \mathrm{W} \pm 0.2038^{\circ} \mathrm{SE}$ ).

One of the units deployed in New Hampshire (W50) had sufficient battery life to provide a complete spring migration route. The spring migration route was the same as for fall migration, with the bird taking an overland route westward through Central America and around the Gulf of Mexico (Fig. 2d), albeit the migration duration was considerably shorter in the spring.

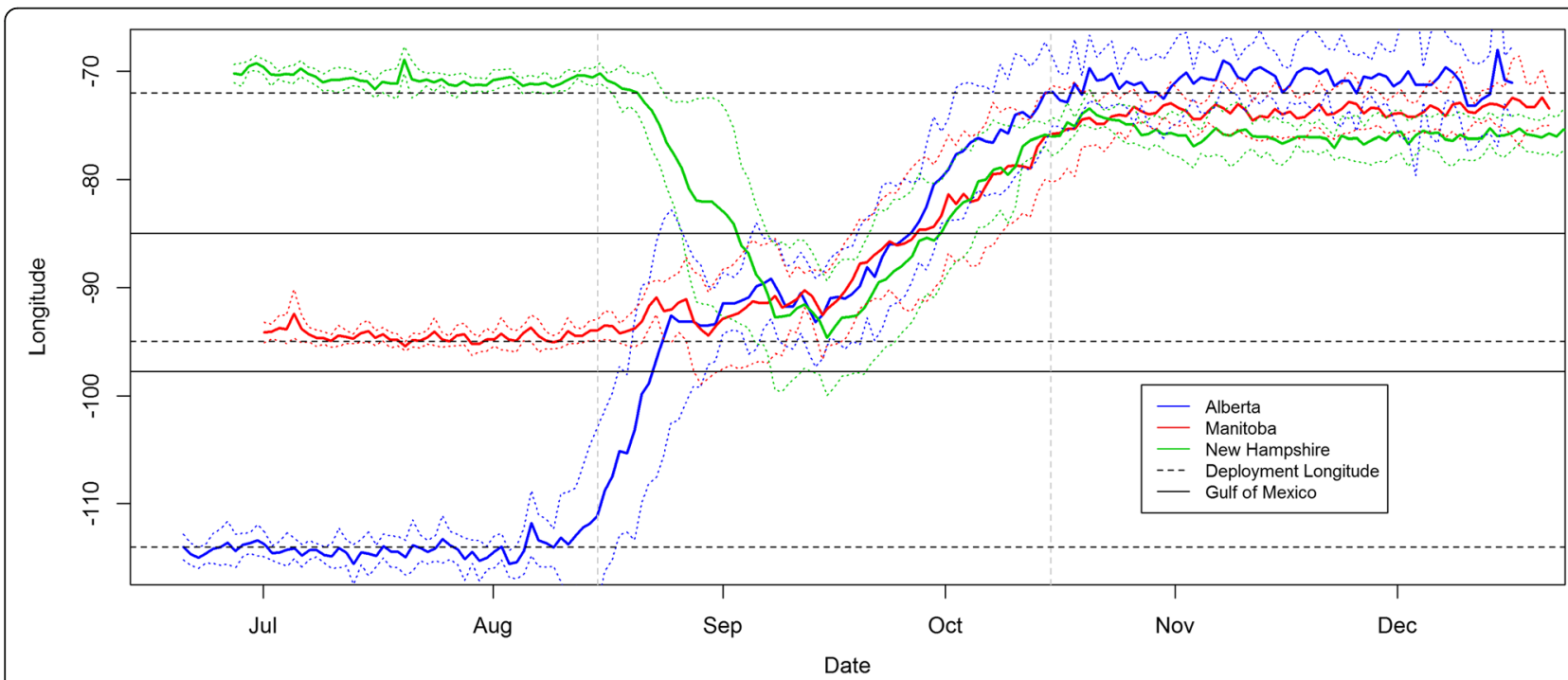

Fig. 1 Average longitudinal positions of 25 male Canada Warblers tracked with light-level geolocators (solid coloured lines) from three different breeding sites in Alberta, Manitoba and New Hampshire (horizontal black dashed lines). The dotted coloured lines around the longitude values indicate plus or minus one standard deviation. The approximate timing of fall migration is bracketed by the grey vertical lines. The most western and eastern limits of the Gulf of Mexico are indicated by horizontal black lines 


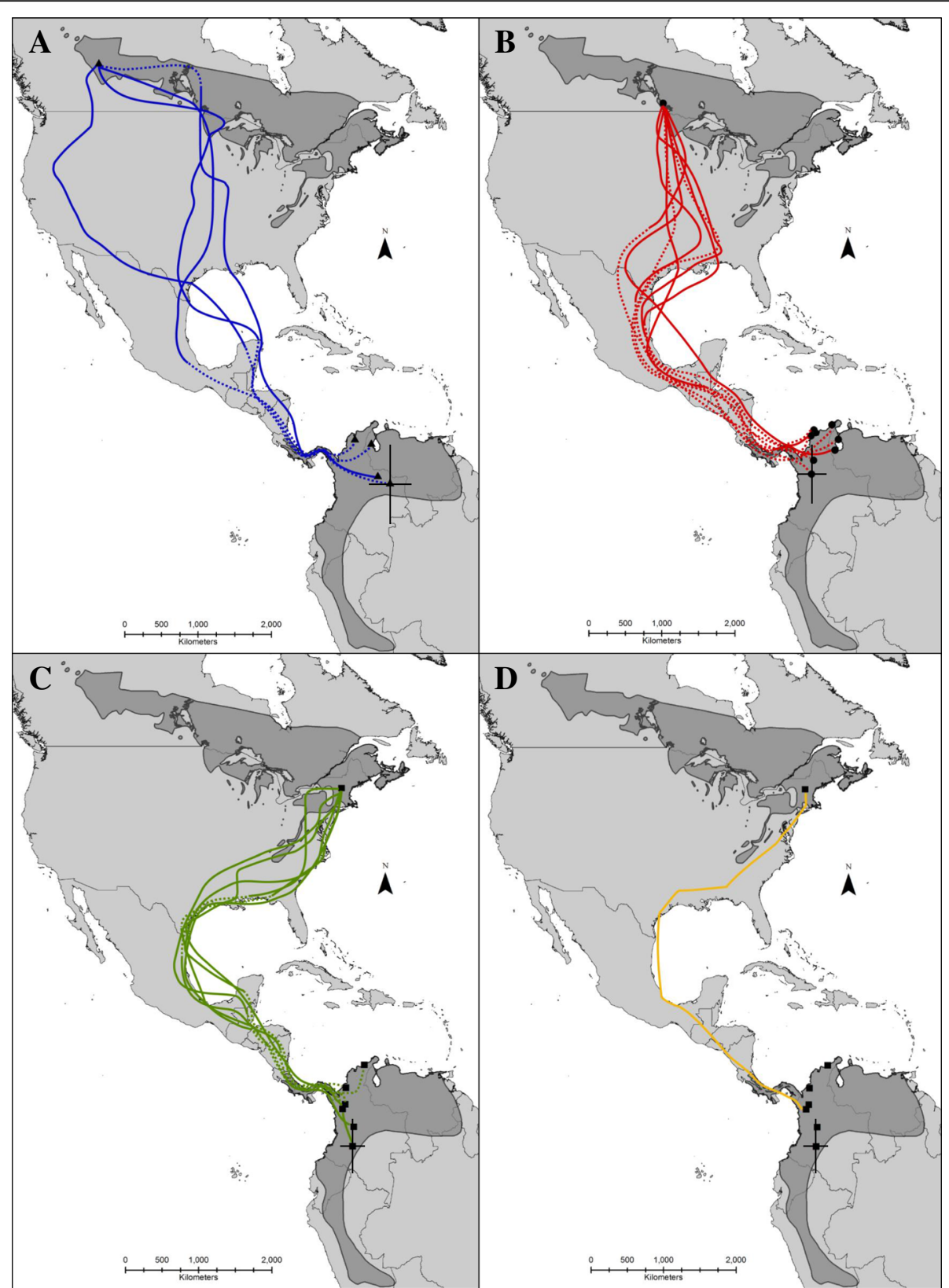

Fig. 2 Estimated migration routes for male Canada Warblers tracked from three breeding populations across the breeding range from 2014 to 2016. Blue tracks represent the fall migration routes taken by 4 individuals that were tracked from Alberta (a), red tracks represent the fall migration routes of 8 individuals from Manitoba (b), green tracks represent the fall migration routes of 6 individuals from New Hampshire (c), and the yellow track shows the spring migration track taken by one individual returning to New Hampshire (d). Dashed lines show inferred routes when latitude estimates were poor. The error bars indicate the average $95 \%$ credible intervals for the overwintering locations shown for each breeding population. The figure was generated in R [54] and the Canada Warbler range map was provided by Environment Canada [18]

\section{Discussion}

We demonstrate that fall migration routes in Canada Warblers largely overlapped for three widely distributed breeding populations. Of the individuals we tracked from across the breeding range spanning approximately 43 degrees in longitude, $77.8 \%$ funnelled into a narrow geographic space on the western side of the Gulf of
Mexico spanning approximately 3 degrees in longitude $\left(97-99^{\circ} \mathrm{W}\right)$ with their migration routes overlapping. Similar patterns of migration have been observed in other species such as the Wood Thrush (Hylocichla mustelina); where $73 \%$ of the individuals tracked from widely distributed breeding populations funneled through a narrow span on the northern coast of the Gulf of 


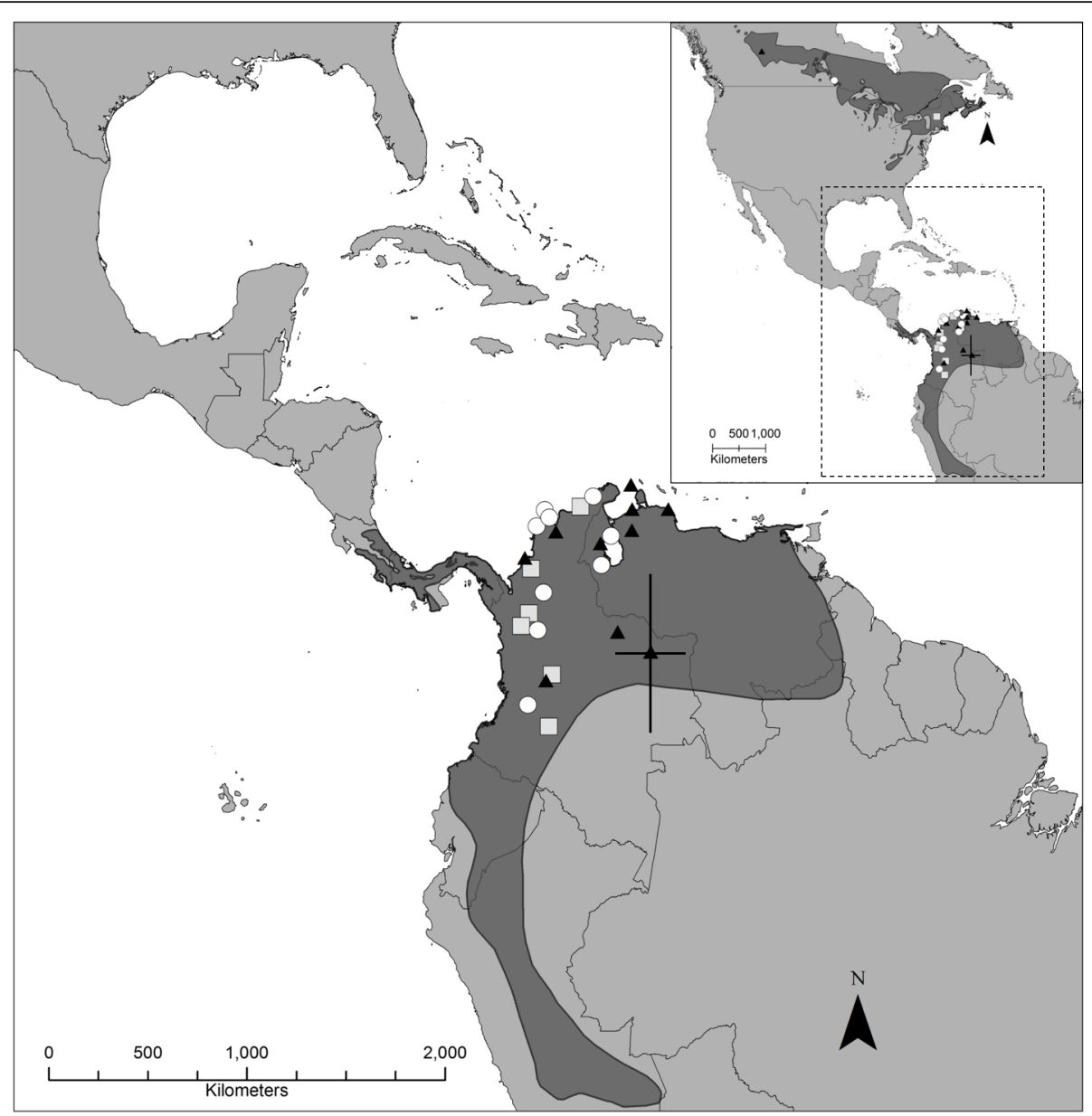

Fig. 3 Average overwintering locations for 25 male Canada Warblers from three different breeding sites determined by using light-level geolocators. The breeding and wintering range are indicated with grey shading. The black triangles indicate individuals that bred in Alberta $(n=10)$, white circles indicate individuals that bred in Manitoba $(n=9)$, and the grey squares represent individuals that bred in New Hampshire $(n=6)$. The error bars indicate the mean 95\% credible intervals for all the overwintering locations. The figure was generated in R [54] and the Canada Warbler range map was provided by Environment Canada [18]

Mexico (between 88 and $93^{\circ}$ longitude) during spring migration [13].

Fall routes were predominantly overland over North America, with the calculated migration routes of some individuals (61.1\% of those tracked) partially crossing or flying across the Gulf of Mexico, before moving through Central America to wintering sites in South America. Despite many Canada Warbler records on islands in the Caribbean, none of the birds we tracked took a trans-Atlantic or island route between North and South America, as taken by Blackpoll Warblers (Setophaga striata) and Connecticut Warblers (Oporornis agilis) $[8,10]$. We therefore infer that the records of Canada Warblers on Caribbean islands likely reflect vagrancy and may not support a primary migration route for this species, supporting the findings of CárdenasOrtiz et al. [34]. However, to confirm this, further eastern-breeding birds should be tracked, as eastern populations would be most likely to use this migration route.

The overlap in Canada Warbler migration routes in the western lowlands of the Gulf of Mexico, and the additional eBird records [60] and band recoveries (Supplemental Figure S1) for the area, indicates that the area may provide important habitat for individuals from across the breeding range during fall migration. Furthermore, Cárdenas-Ortiz et al. [34] observed individuals from across the breeding range converging at the Darién in Northern Colombia and suggested that individuals traveling southward through Central America may concentrate in this region during fall migration. Conservation of stopover habitat surrounding the Gulf of Mexico and throughout Central America may therefore support breeding populations from across the range, as it is an important thoroughfare for multiple breeding populations [61]. 
The migration routes of the Alberta and Manitoba populations overlapped greatly. The eastward movement exhibited at the onset of fall migration by $75 \%$ of the birds tracked from Alberta resulted in spatial and temporal overlap between the migration routes of the Alberta and Manitoba populations as they moved southward. These results suggest that individuals that breed in Alberta and Manitoba may share many of the same threats during migration and at stopover sites. Furthermore, variation in the habitat use at a population-level upon leaving the breeding sites could contribute to population specific threats. For example, the predominantly coastal route taken by individuals from New Hampshire to the Gulf of Mexico could expose these individuals to different pressures. Specifically, birds using the New Hampshire migration route likely encounter more forest loss due to urban development and timber cutting on their initial movement south [62]. Differing rates of survival have been observed across the Canada Warbler breeding range, with productivity remaining constant. Survival is low at the east and west extents of the breeding range, with the steepest declines in abundance in the east [63]. The impact of migration routes on these patterns of survival should be further investigated.

Our results show that deployment site was an important predictor of recovery rate. We did not recover any units from Québec, while the recovery rates from the other sites ranged from 10 to $35 \%$. Differing return rates could be linked to variable rates of survival across the range, however, this was not directly tested and a number of other factors likely impacted return rates. We deployed the fewest tags in Québec $(n=16)$, and most of the suitable Canada Warbler habitat at this site was roadside habitat, with alternate sites being inaccessible. In 2016, in Québec, unbanded territorial males claimed the breeding territories where deployment took place, but it was not possible to survey the $500 \mathrm{~m}$ area surrounding the deployment site. The lack of accessibility to habitat surrounding the deployment location likely affected the recovery rate. The subsequent year in 2017, two banded individuals were observed in the area, recaptured, and were confirmed to have been two individuals from the 2015 deployment, but had returned without their geolocators. Therefore in this case, site specific factors likely impacted the disparity in return rates.

We documented some within-population variation in fall migration routes between breeding sites and the Gulf of Mexico. Of the four individuals from the westernmost tracking site, three moved eastwards, while one individual initially traveling southwest before overlapping at the Gulf of Mexico with the routes of the other individuals tracked from western and central breeding locations. Observational data of Canada Warblers during fall migration through far-western North America have been logged on eBird [60] and are represented in published records [64, 65]. Our results suggest, not surprisingly, that birds occurring in these areas during fall may be derived from breeding populations in more western portions of the range, such as those in Alberta and westward. It is possible that the fourth individual navigated the Rocky Mountains, resulting in the difference in routes. Regardless of the route, all four individuals tracked from the west of the breeding range demonstrated that some individuals may not travel the shortest distance to the Gulf of Mexico, as would be expected in parallel migration [37] and observed for fall migration in Veeries (Catharus fuscescens) [66] and Purple Martins (Progne subis) [38], as well as many species of AfroPalaearctic landbirds navigating the Sahara [40]. In the case of Alberta breeders, these observed routes to the east and west rather than south, may be driven by the open, largely agricultural zone that occurs directly to the south of the Alberta breeding site. This may be unsuitable to migrating Canada Warblers, which have highly specific habitat preferences and seek dense cover during migration [67]. When comparing habitat use during spring migration in seven habitat types, Power [67] observed $76.5 \%$ in floodplain forest while the remaining observations were all in oak-hardwood forest. Canada Warblers have been primarily reported in forests with dense shrubs and thickets, often near watercourses, during migration [19]. However, non-direct routes may not necessarily be tied to stopover habitat preferences and may reflect ancestral migration patterns that were retained following breeding range expansion, as has been observed in the Swainson's Thrush (Catharus ustulatus) [68] and Veery [66].

A novel finding of our study was the most probable migration route of $61.1 \%$ of all individuals crossing or transecting the Gulf of Mexico. It had been previously unresolved as to whether Canada Warblers cross the Gulf of Mexico during migration (but see [34]). They have been largely considered a circum-Gulf migrant with a migration route described as hugging the coast of the Gulf of Mexico [69]. Additionally, the Yucatan Peninsula, an area used by many species that perform a transGulf migration [7, 13, 70, 71] is typically considered to be outside of the Canada Warbler migration pathway, as defined by the conventional species' range map $[17,18]$. However, there are published reports of Canada Warblers for the Yucatan [72, 73] as well as eBird records [60]. Our results indicate that, although it was not the predominant route, some Canada Warblers may cross the Gulf of Mexico to the Yucatan Peninsula during fall migration. Due to the error associated with geolocators (Fig. 4), it is difficult to ascertain specific stopover locations and fine-scale movements around the Gulf of Mexico. As such, stopover behaviour and migratory 

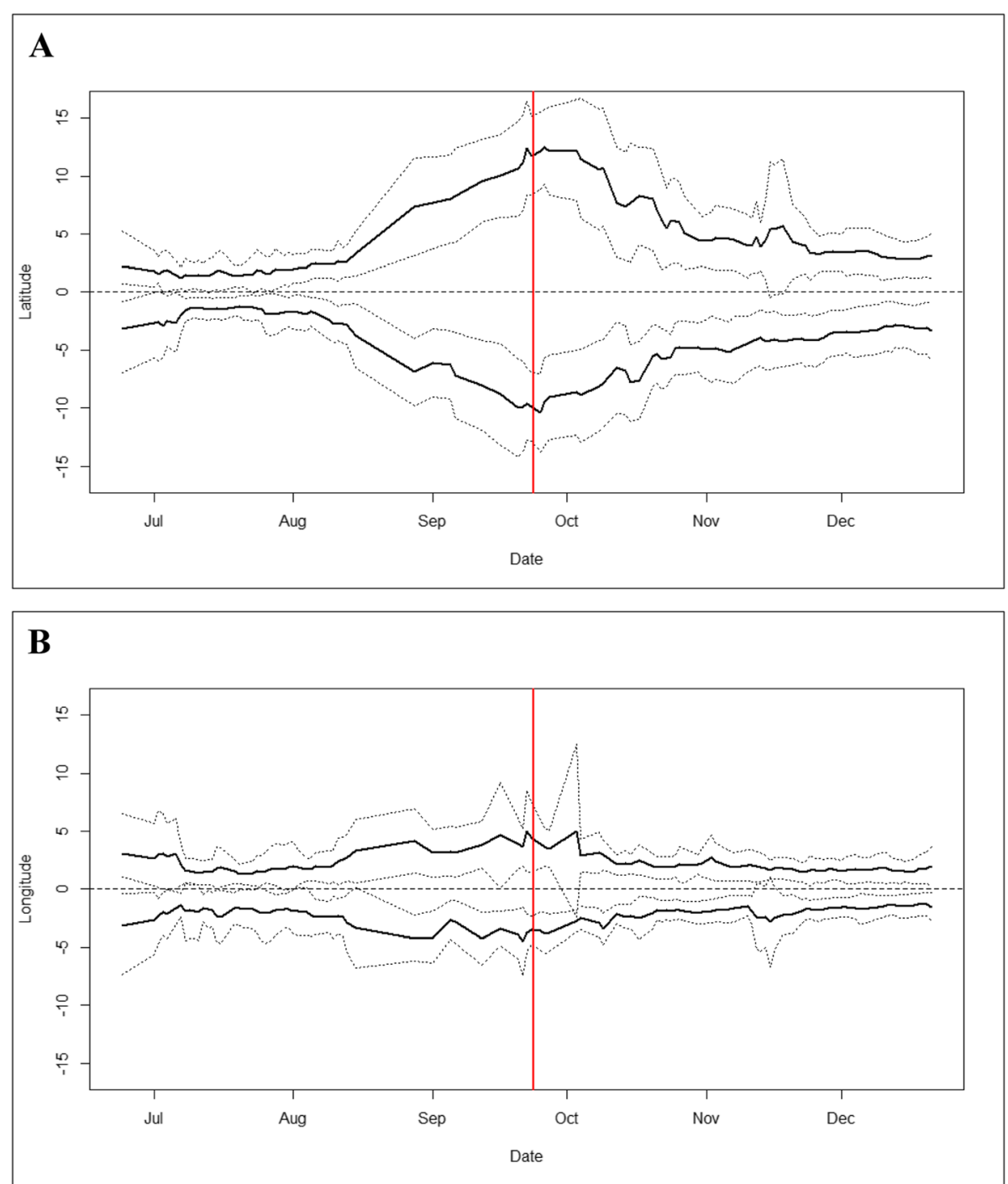

Fig. 4 Average 95\% credible intervals for a) latitude and b) longitude values derived by FLightR analysis for 18 male Canada Warblers tracked with light-level geolocators from breeding sites in Alberta, Manitoba and New Hampshire. The dotted lines around the longitude curves indicate plus or minus one standard deviation. The fall equinox is indicated by the red vertical line

behaviour, as well as habitat use by Canada Warblers migrating through Central America needs to be further explored, specifically in the Yucatan, and the Gulf of Mexico, to better direct conservation in these regions.

The individual that was tracked during spring migration as well as fall migration took a circum-Gulf migration route for both. It has been hypothesized that Canada Warblers may make a trans-Gulf crossing in the spring when the wind conditions are more favourable [74], but the spring migration track for this individual did not support this. Additional tracking of spring migration should be conducted to confirm or refute whether this track reflects typical spring migration patterns for this species. Additionally, population-specific migration routes may exist for spring, which may provide an important source of variation in space-use, and could result in population level effects. To address this, future research should be focused on tracking the spring migration of Canada Warblers.

While we measured a high degree of overlap in migration routes at the Gulf of Mexico, we observed some partitioning of different breeding populations at overwintering sites. Generally, we found that the westernmost breeding population overwintered farthest to the east, and the easternmost breeding population overwintered farthest to the west. This contrasts with what has been observed in many songbird species where strong parallel patterns of migratory connectivity between breeding and overwintering areas have been found [13, 75]. However, this crossing pattern in migratory movements has been observed in 
other warbler species, like the Yellow Warbler (Setophaga petechia) [76]. This result also contrasts with observations made by González-Pietro et al. [41] based on analysis of stable hydrogen isotope ratios of Canada Warblers in three different cordilleras in the Colombian Andes. Stable hydrogen isotope ratios suggest that individuals from the eastern Andes correspond to the eastern breeding range, and individuals from the western Andes corresponding to the western breeding range. This study removed six statistical outliers from their analysis to comply with the principle of parsimony, however the six statistical outliers were all sampled from the same location (Santander, Colombia) and exhibited stable hydrogen ratios reflective of the northwestern-most breeding range. Though the sample size was small, these statistical outliers corroborate the crosswise migration path detected herein using lightlevel geolocators, and signals the potential for different migration paths between populations. As stated by González-Pietro et al. [41], more sampling of the area should be conducted at a larger scale to address whether the pattern of isotopic signatures holds true and future research should be aimed to address the question of migratory connectivity in the Canada Warbler. Furthermore, we could not explore the potential for within-winter movements with this study, as the positional error associated with the non-breeding estimates could not be separated from true movement during the winter. This would be an important investigation to support future conservation of overwintering habitat, to determine whether individuals are largely sedentary or are more mobile during the non-breeding season.

Most of the individuals we tracked (72\%) overwintered in Colombia, primarily overwintering in the Caribbean region of Colombia, suggesting the conservation value of preserving habitat in this region for birds from across the breeding range. It is both possible that we simply did not track individuals that overwinter in other regions of the wintering grounds and that the Caribbean region offers overwintering territories to the majority of the Canada Warbler population. As no individuals were tracked from the southern portion of the breeding range and no individuals wintered in the southwestern region of the overwintering range, it is also possible that Canada Warblers exhibit a chain migration, where individuals breeding furthest south also overwinter the furthest south [37]. However, tracking of southern breeding populations will be required to determine whether this is the case. Alternatively, similar patterns of convergence from across the breeding range into remarkably smaller overwintering locations have been reported in several other species, including Bobolinks (Dolichonyx oryzivorus) [77], Purple Martins [12] and Prothonotary Warblers (Protonotaria citrea) [78]. Geolocator tracking of Prothonotary Warblers showed $91 \%$ of individuals tracked funneled predominantly to overwintering sites in Colombia in a small section of the wintering grounds, similarly to our results. As recommended by Tonra et al. [78] for Prothonotary Warblers, we recommend that wintering areas not identified by geolocators be investigated and that individuals occurring here be studied to identify their breeding origins. Species with concentrated wintering areas have been identified as further at risk for population declines than those with larger wintering extents [79].

It is suspected that population declines in Canada Warblers is due, in part, to habitat loss on the wintering grounds [18]. Our results suggest it is possible that the effects of habitat loss in Colombia are exacerbated by the relatively limited geographic dispersion of individuals in our study. Dramatic forest losses have been observed in Colombia [80-82] with high rates of deforestation [83] driven largely by habitat being cleared for cultivation [84], pastures, and human settlements [85]. Historical forest loss in this region has been linked to declines in other songbird species (e.g., Golden-winged Warblers (Vermivora chrysoptera) [11]) and may also be a factor leading to population declines in Canada Warblers. The Caribbean region in Colombia, where most tracked Canada Warbler individuals overwintered, has the lowest amount of remaining forest and the second highest rate of deforestation in the country [85]. Some forest recovery in Colombia has been reported in the last decade [86], and there is a need to carefully plan their management going forward [87]. Responsible agricultural development in South America has the opportunity to safeguard the survival of overwintering Canada Warblers. González et al. [88] demonstrated that overwintering sites in shade grown coffee plantations with high canopy cover offers similar quality habitat to Canada Warblers when compared to intact forest. The authors suggest that an approach that enables the retention of native forest while developing portions for shade coffee may mutually benefit both overwintering migratory birds and the needs of local communities. The conservation of Canada Warblers and other migratory songbirds will rely on concerted protection and careful management of remaining habitat within Colombia and throughout South America.

\section{Conclusions}

Our results provide new information on the broad scale annual movements of Canada Warblers addressing major knowledge gaps on their migratory routes and distribution. These could be complemented by future studies focused on determining migratory habitat use at finer-scales, using new technologies such as Motus Wildife Tracking Network (radio telemetry arrays that study movements of small tagged animals [89]), to target precise locations for conservation actions [90]. Due to 
the amount of latitudinal error, we were unable to provide temporal information regarding migration and specific stop over locations. We recommend this as an opportunity for future research. Future studies could also target quantitative measures of range-wide migratory connectivity, determining spring migration routes for multiple populations, and migratory strategies of female Canada Warblers. We hope that our results provide a starting point and will stimulate more fine-scale land use and habitat studies to further promote the conservation of habitat for migratory species through Central America and South America.

\section{Supplementary information}

Supplementary information accompanies this paper at https://doi.org/10. 1186/s40850-020-00056-4.

Additional file 1: Table S1- Overview of published Canada Warbler records during the migratory period [26-32, 72, 73, 91-103].

Additional file 2: Table S2- Comparison of logistic regression models to identify predictors of return rates of Canada Warblers $(n=148)$. Models included deployment site $(\mathrm{S})$, geolocator type $(\mathrm{G})$, harness type $(\mathrm{H})$, deployment age (A) and deployment year $(\mathrm{Y})$ as independent variables. Models with $\triangle$ AIC less than 2 are highlighted in bold.

Additional file 3: Figure S1- Canada Warbler range map showing where individual birds were banded and recovered (connected by black lines) during migration or in the wintering grounds from 1960 to 2015. Two individuals were banded and recovered at the same location. Only six of the band recoveries were obtained during migration (one in Missouri, four in Texas and one in El Salvador) and one was recovered during the wintering period in Colombia. Data provided by the Canadian Bird Banding Office [25]. The figure was generated in ArcMap and the range map was provided by Environment Canada [18], and was adapted from a previous BirdLife [91] and NatureServe distribution map using data from eBird [60] and the Boreal Avian Modelling Project.

\section{Abbreviations}

SY: Second Year; ASY: After Second Year; FERS: Forêt d'Enseignement et de Recherche Simoncouche; UQAC: Université du Québec in Chicoutimi; GPS: Geographic Positioning System; AIC: Akaike Information Criterion

\section{Acknowledgements}

We thank the many individuals and organizations that assisted in the deployment and recovery of the geolocators, reviewers that provided valuable input on early drafts of this manuscript, as well as the funding agencies that made this work possible. We thank Nicole Krikun, Kevin Methuen, Sabina Mastrolonardo, Kelsey Bell, Steve Andersen, Kyle Ritchie, Samantha Fulton, Christian Burns, Hannah Elzinga, Charlotte Harding, and Bruno Drolet for field support. We thank Geoff Holroyd, Christa Burstahler, Christian Artuso, Gail Davoren and Kevin Methuen for editing early drafts of this manuscript. We thank Nathan Cooper, Eldar Rakhimberdiev, Simeon Lisovski, Gunnar Kramer, and Emily McKinnon for their assistance with analysis. We thank Alberta Parks, Manitoba Parks, and FERS-UQAC (especially Patrick Nadeau) for allowing access to the deployment sites and logistical support in Alberta, Manitoba and Québec respectively.

\section{Authors' contributions}

ARC and KCF conceived and developed the study. ARC, JK, LR, JAT, RK, KAH, $\mathrm{JI}$ and KCF conducted field work and contributed to data collection. ARC performed the analysis, and wrote the manuscript. ARC, JK, LR, JAT, RK, KAH, $\mathrm{JI}$ and KCF contributed to editing the manuscript and all authors read and approved the final manuscript.

\section{Funding}

The design of the study and collection, analysis, and interpretation of data and the writing the manuscript were supported by the University of Manitoba and NSERC. The collection of data was supported by Environment and Climate Change Canada, TD Friends of the Environment, the Boreal Songbird Initiative, Manitoba Sustainable Development, the Lesser Slave Lake Bird Observatory, Plymouth State University, the Mascoma Watershed Conservation Council, and FERS-UQAC.

\section{Availability of data and materials}

The data used during the current study are available from the corresponding author on reasonable request.

\section{Ethics approval and consent to participate}

This research was conducted in compliance with the Guidelines to the Use of Wild Birds in Research, with approval from the University of Manitoba's Animal Care Committee (F14-009/1), and with all the necessary provincial, state and federal permits required.

\section{Consent for publication}

Not applicable.

\section{Competing interests}

None of the authors have any competing interests.

\section{Author details}

${ }^{1}$ Department of Biological Sciences, University of Manitoba, Winnipeg, Manitoba, Canada. ${ }^{2}$ Environment and Climate Change Canada, Canadian Wildlife Service, Gatineau, Québec, Canada. ${ }^{3}$ Department of Biological Sciences, Plymouth State University, Plymouth, NH, USA. ${ }^{4}$ Environment and Climate Change Canada, Science and Technology Branch, Québec, Canada. ${ }^{5}$ Département des sciences fondamentales, Université du Québec à Chicoutimi, Saguenay, Canada. ${ }^{6}$ Lesser Slave Lake Bird Observatory, Slave Lake, Alberta, Canada. ${ }^{7}$ Environment and Climate Change Canada, Science and Technology, Saskatoon, SK, Canada.

Received: 20 August 2019 Accepted: 18 June 2020

Published online: 31 July 2020

\section{References}

1. Robbins CS, Sauer JR, Greenberg RS, Droege S. Population declines in north American birds that migrate to the Neotropics. Proc Natl Acad Sci USA. 1989;86:7658-62.

2. Faaborg J, Holmes RT, Anders AD, Bildstein KL, Dugger KM, Gauthreaux SA, Heglund P, Hobson KA, Jahn AE, Johnson DH, Latta SC. Conserving migratory land birds in the New World: do we know enough? Ecol Appl. 2010a;20(2):398-418

3. Sauer JR, Niven DK, Hines JE, Ziolkowski DJ Jr, Pardieck KL, Fallon JE, Link WA. The north American breeding bird survey, results and analysis 19662015. Laurel: USGS Patuxent Wildlife Research Center; 2017.

4. Rosenberg KV, Dokter AM, Blancher PJ, Sauer JR, Smith AC, Smith PA, Stanton JC, Panjabi A, Helft L, Parr M, Marra PP. Decline of the north American avifauna. Science. 2019;366:120-4.

5. North American Bird Conservation Initiative Canada. The state of Canada's birds, 2012. Ottawa: Environment Canada; 2012.

6. Faaborg J, Holmes RT, Anders AD, Bildstein KL, Dugger KM, Gauthreaux SA, Heglund P, Hobson KA, Jahn AE, Johnson DH, Latta SC. Recent advances in understanding migration systems of New World land birds. Ecol Monogr. 2010b;80:3-48.

7. Stutchbury BJM, Tarof SA, Done T, Gow E, Kramer PM, Tautin J, Fox JW, Afanasyev $\mathrm{V}$. Tracking long-distance songbird migration by using geolocators. Science. 2009;323:896.

8. McKinnon EA, Artuso C, Love OP. The mystery of the missing warbler. Sci Nat. 2017:1-3.

9. McKinnon EA, Love OP. Ten years tracking the migrations of small landbirds: lessons learned in the golden-age of biologging. Auk. 2018;135(4):834-56.

10. DeLuca W, Woodworth BK, Rimmer CC, Marra PP, Taylor PD, McFarland KP, Mackenzie SA, Norris DR. Transoceanic migration by a $12 \mathrm{~g}$ songbird. Biol Lett. 2015;11:1-4.

11. Kramer GR, Andersen DE, Buehler DA, Wood PB, Peterson SM, Lehman JA Aldinger KR, Bulluck LP, Harding S, Jones JA, Loegering JP, Smalling C, 
Vallender R, Streby HM. Population trends in Vermivora warblers are linked to strong migratory connectivity. Proc Natl Acad Sci. 2018;115:3192-200.

12. Fraser KC, Stutchbury BJM, Sllverio C, Kramer PM, Barrow J, Newstead D, Mickle N, Cousens BF, Lee JC, Morrison DM, Shaheen T, Mammenga P, Applegate $\mathrm{K}$, Tautin J. Continent-wide tracking to determine migratory connectivity and tropical habitat associations of a declining aerial insectivore. Proc Royal Soc Biol Sci. 2012;279:4901-6.

13. Stanley CQ, McKinnon EA, Fraser KC, Macpherson MP, Casbourn G, Friesen L, Marra PP, Studds C, Ryder TB, Diggs NE, Stutchbury BJ. Connectivity of wood thrush breeding, wintering, and migration sites based on range-wide tracking. Conserv Biol. 2014;29:164-74.

14. English PA, Mills AM, Cadman MD, Heagy AE, Rand GJ, Green DJ, Nocera JJ. Tracking the migration of a nocturnal aerial insectivore in the Americas. BMC Zool. 2017;2(5).

15. COSEWIC. COSEWIC assessment and status report on the Canada warbler (Wilsonia canadensis) in Canada: Committee on the Status of Endangered Wildlife in Canada; 2008. Retrieved from www.sararegistry.gc.ca/status/ status_e.cfm. Accessed on Dec 2016. Accessed again on 26 July 2020.

16. Wells J., D. Childs, F. Reid, K. Fraser, A. Roberto-Charron, J. Fitzpatrick, M. Darveau, K. Smith, and S. Bonfield (2016). Charting a healthy future for North America's birds: 100 years after the migratory bird treaty, innovative conservation and technology essential to overcome new challenges. Boreal Songbird Initiative, Seattle, Washington, Cornell Lab of Ornithology, Ithaca, New York, Ducks Unlimited Inc., Memphis, Tennessee, Ducks Unlimited Canada, Stonewall, Manitoba, and Environment for the Americas, Boulder, Colorado.

17. Reitsma LR, Goodnow M, Hallworth MT, Conway CJ. Canada warbler (Cardellina canadensis), the birds of North America (P.G. Rodewald, Ed.). Ithaca: Cornell Lab of Ornithology; 2009. Retrieved from the Birds of North America: https://birdsna-org.uml.idm.oclc.org/Species-Account/bna/species/ canwar. Accessed 12 May 2017.

18. Environment Canada. Recovery strategy for Canada warbler (Cardellina canadensis) in Canada [proposed]. Species at risk act recovery strategy series. Ottawa: Environment Canada; 2015.

19. Lambert JD, Faccio SD. Canada warbler population status, habitat use, and stewardship guidelines for northeastern forests, Vermont institute of natural science technical report; 2005. p. 05-4.

20. Hallworth M, Ueland A, Anderson E, Lambert JD, Reitsma L. Habitat selection and site fidelity of Canada warblers (Wilsonia canadensis) in Central New Hampshire. Auk. 2008;125:880-8.

21. Reitsma LR, Hallworth MT, Benham PM. Does age influence territory size, habitat selection, and reproductive success of male Canada warblers in Central New Hampshire? Wilson J Ornithology. 2008;120:446-54.

22. Sleep D, Drever MC, Szuba KJ. Potential role of spruce budworm in rangewide decline of Canada warbler. J Wildl Manag. 2009;73:546-55.

23. Goodnow ML, Reitsma LR. Nest-site selection in the Canada warbler (Wilsonia canadensis) in Central New Hampshire. Can J Zool. 2011;89:1172-7.

24. Ball J, Sólymos P, Schmiegelow F, Hache S, Schieck J, Bayne E. Regional habitat needs of a nationally listed species, Canada warbler (Cardellina canadensis), in Alberta, Canada. Avian Conserv Ecol. 2016;11(2).

25. Canadian Bird Banding Office. Unpublished data retrieved May, 2016. Ottawa: Canadian Wildlife Service, Environment and Climate Change Canada; 2016.

26. Prins TG, Debrot AO. First record of the Canada warbler for Bonaire, Netherlands Antilles. Caribb J Sci. 1996;32:248-9.

27. Monroe BL. A distributional survey of the birds of Honduras. Ornithol Monogr. 1968;7:1-458.

28. Land HC. The birds of Guatemala. Wynnewood: Livingston Publishing Co:; 1970.

29. Greenberg RS, Gradwohl JA. Observations of paired Canada warblers Wilsonia canadensis during migration in Panama. Ibis. 1980;122:509-12.

30. Binford LC. A distributional survey of the birds of the Mexican state of Oaxaca. Ornithological Monographs. No. 43. American Ornithologists' Union; 1989.

31. Leyva EM, Inzunza ER, Carretero OC, Barr JL, Peresbarabosa Rojas E, Chavez Dominguez I, Ramon Lara G, Rodriguez Mesa R, Miranda AG, Dominguez NF. Dynamics of passerine migration in Veracruz, México, Proceedings of the Fourth International Partners in Flight Conference: Tundra to Tropics; 2009. p. 62-70.

32. Wolfe JD, Johnson MD, Ralph CJ. Do birds select habitat or food resources? Nearctic-Neotropic migrants in northeastern Costa Rica. PLoS One. 2014;9:1-9.
33. Cramp S. The birds of the Western Palearctic, vol. IV. Oxford: Warblers. Oxford University Press; 1992.

34. Cárdenas-Ortiz L, Bayly NJ, Colorado GJZ, Hobson KA. Fall migration and breeding origins of Canada warblers moving through northern Colombia. J Field Ornithol. 2017;88:53-64.

35. Curson J, Quinn D, Beadle D. Warblers of the Americas: an identification guide. New York: Houghton Mifflin Harcourt; 1994.

36. Webster MS, Marra PP, Haig SM, Bensch S, Holmes RT. Links between worlds: unraveling migratory connectivity. Trends Ecol Evol. 2002;17(2): 76-83.

37. Newton I. The migration ecology of birds. London: Academic Press; 2008.

38. Fraser KC, Stutchbury BJ, Kramer P, Silverio C, Barrow J, Newstead D, Mickle $\mathrm{N}$, Shaheen T, Mammenga P, Applegate K, Bridge E. Consistent range-wide pattern in fall migration strategy of purple martin (Progne subis), despite different migration routes at the Gulf of Mexico. Auk. 2013:130:291-6.

39. Kramer GR, Streby HM, Peterson SM, Lehman JA, Buehler DA, Wood PB, McNeil DJ, Larkin JL, Andersen DE. Nonbreeding isolation and populationspecific migration patterns among three populations of Golden-winged warblers. Condor. 2017:119:108-21.

40. Briedis M, Bauer S, Adamík P, Alves JA, Costa JS, Emmenegger T, Gustafsson L, Koleček J, Krist M, Liechti F, Lisovski S. Broad-scale patterns of the afroPalaearctic landbird migration. Glob Ecol Biogeogr. 2020.

41. González-Prieto AM, Bayly NJ, Colorado G, Hobson KA. Topography of the Andes Mountains shapes the wintering distribution of a migratory bird. Divers Distrib. 2016;23(2):118-29.

42. Hewson CM, Thorup K, Pearce-Higgins JW, Atkinson PW. Population decline is linked to migration route in the common cuckoo. Nat Commun. 2016;7:1-8.

43. Fair J, Paul E, Jones J. Guidelines to the use of wild birds in research. Washington, D.C.: Ornithological Council; 2010.

44. Rappole, J. H., and A.R. Tipton (1991). New harness design for attachment of radio transmitters to small passerines (Nuevo Diseño de Arnés Para Atar Transmisores a Passeriformes Pequeños). J Field Ornithol 62:335-337.

45. Streby HM, McAllister TL, Peterson SM, Kramer GR, Lehman JA, Andersen DE. Minimizing marker mass and handling time when attaching radiotransmitters and geolocators to small songbirds. Condor. 2015;117:249-55.

46. Naef-Daenzer B. An allometric function to fit leg-loop harnesses to terrestrial birds. J Avian Biol. 2007:38:404-7.

47. Pyle, P. 1997. Identification guide to north American birds. Slate creek press. Bolinas, CA. R Core Team 2013. www.R-project.org/. Accessed 12 May 2017.

48. Peterson SM, Streby HM, Kramer GR, Lehman JA, Buehler DA, Andersen DE. Geolocators on Golden-winged warblers do not affect migratory ecology. Condor. 2015;117:256-61.

49. Hill RD, Braun MJ. Geolocation by light level. Electronic tagging and tracking in marine fisheries. Netherlands: Springer; 2001. p. 315-30.

50. Lisovski S, Bauer S, Briedis M, Davidson SC, Dhanjal-Adams KL, Hallworth MT, Karagicheva J, Meier CM, Merkel B, Ouwehand J, Pedersen L, Rakhimberdiev E, Roberto-Charron A, Seavy NE, Sumner MD, Taylor CM, Wotherspoon SJ, Bridge ES. Light-level geolocator analyses: a user's guide. J Anim Ecol. 2019; 00:1-16.

51. Rakhimberdiev E, Winkler DW, Bridge E, Seavy NE, Sheldon D, Piersma T, Saveliev A. A hidden Markov model for reconstructing animal paths from solar geolocation loggers using templates for light intensity. Mov Ecol. 2015 3(1):15.

52. Lisovski $\mathrm{S}$, Hewson CM, Klaassen RH, Korner-Nievergelt F, Kristensen MW, Hahn S. Geolocation by light: accuracy and precision affected by environmental factors. Methods Ecol Evol. 2012:3:603-12.

53. Wotherspoon, S., M. Sumner and S. Lisovski (2013). BAStag: basic data process for light based geolocation archival tags. R package version 0.1-3.

54. Core Team R. R: a language and environment for statistical computing. Vienna: R Foundation for Statistical Computing; 2017. http://www.R-project.org/.

55. Rakhimberdiev E, Saveliev A, Piersma T, Karagicheva J. FLight R: an R package for reconstructing animal paths from solar geolocation loggers. Methods Ecol Evol. 2017:8:1482-7.

56. Rakhimberdiev E and A. Saveliev (2016a)._FLightR: SSM for solar geolocation. R package version 0.4.1. URL: http://github.com/eldarrak/ FLightR. Accessed 12 May 2017.

57. Rakhimberdiev E, Senner NR, Verhoeven MA, Winkler DW, Bouten W, Piersma T. Comparing inferences of solar geolocation data against highprecision GPS data: annual movements of a double-tagged black-tailed godwit. J Avian Biol. 2016b;47(4):589-96. 
58. ESRI. ArcGIS Desktop: Release 10.2. Redlands: Environmental Systems Research Institute; 2013.

59. Burnham KP, Anderson DR. Model selection and multimodel inference: a practical information-theoretic approach. New York: Springer; 2002.

60. eBird. eBird: an online database of bird distribution and abundance [web application]. Ithaca: eBird, Cornell Lab of Ornithology; 2017. Available: http:// www.ebird.org. Accessed 2 Feb 2016.

61. Cardenas-Ortiz L, Bayly NJ, Kardynal KJ, Hobson KA. Defining catchment origins of a geographical bottleneck: implications of population mixing and phenological overlap for the conservation of Neotropical migratory birds. Condor. 2020;122:1-13

62. Drummond MA, Loveland TR. Land-use pressure and a transition to forestcover loss in the eastern United States. BioScience. 2010;60:286-98.

63. Wilson S, Saracco JF, Krikun R, Flockhart DT, Godwin CM, Foster KR. Drivers of demographic decline across the annual cycle of a threatened migratory bird. Sci Rep. 2018:8(1):1-11.

64. Small A. California birds: their status and distribution. Vista: Ibis Publishing Co.; 1994.

65. Gilligan J, Rogers D, Smith M, Contreras A. Birds of Oregon: status and distribution. McMinnville: Cinclus Publications; 1994.

66. Kardynal KJ, Hobson KA. The pull of the central flyway? Veeries breeding in western Canada migrate using an ancestral eastern route. J Field Ornithol. 2017:88(3):262-73.

67. Power DM. Warbler ecology: diversity, similarity, and seasonal differences in habitat segregation. Ecology. 1971;52:434-43.

68. Ruegg KC, Smith TB. Not as the crow flies: a historical explanation for circuitous migration in Swainson's thrush (Catharus ustulatus). Proc R Soc B. 2002;269:1375-81

69. Shackelford CE, Rozenburg ER, Hunter WC, Lockwood MW. Migration and the migratory birds of Texas: who they are and where they are going, Texas parks and wildlife PWD BK W7000-511; 2005. p. 1-34.

70. Hobson KA, Kardynal KJ. Western Veeries use an eastern shortest-distance pathway: new insights to migration routes and phenology using light-level geolocators. Auk. 2015;132:540-50.

71. Wolfe JD, Johnson El. Geolocator reveals migratory and winter movements of a Prothonotary warbler. J Field Ornithol. 2015:86:238-43.

72. Paynter RA. Autumnal trans-gulf migrants and a new record for the Yucatan peninsula. Auk. 1951;68:113-4.

73. Tellkamp MP, Martin TH. Noteworthy bird records from southern Yucatán state, México. Cotinga. 2015:37:18-21.

74. Kranstauber B, Weinzierl R, Wikelski M, Safi K. Global aerial flyways allow efficient travelling. Ecol Lett. 2015;18:1338-45.

75. Boulet M, Gibbs HL, Hobson KA. Integrated analysis of genetic, stable isotope and banding data reveal migratory connectivity and flyways in the northern yellow warbler (Dendroica petechia; Aestiva group). Ornithol Monogr. 2006;61:29-78.

76. Witynski ML, Bonter DN. Crosswise migration by yellow warblers, nearcticneotropical passerine migrants. J Field Ornithol. 2018

77. Renfrew RB, Kim D, Perlut N, Smith J, Fox JW, Marra PP. Phenological matching across hemispheres in a long-distance migratory bird. Divers Distrib. 2013;19:1008-19.

78. Tonra CM, Hallworth MT, Boves TJ, Reese J, Bulluck LP, Johnson M, Viverette C, Percy K, Ames EM, Matthews A, Slevin MC. Concentration of a widespread breeding population in a few critically important nonbreeding areas: migratory connectivity in the Prothonotary warbler. Condor. 2019;121.

79. Gilroy JJ, Gill JA, Butchart SH, Jones VR, Franco AM. Migratory diversity predicts population declines in birds. Ecol Lett. 2016:19:308-17.

80. Etter A, McAlpine C, Pullar D, Possingham H. Modelling the conversion of Colombian lowland ecosystems since 1940: drivers, patterns and rates. J Environ Manag. 2006;79:74-87.

81. Cabrera E, Vargas DM, Galindo MC, García G, Ordoñez MF, Vergara LK, Pacheco AM, Rubiano JC, Giraldo P. Memoria técnica de la cuantifi cación de la deforestación histórica nacional - escalas gruesa y fina. Bogotá: Instituto de Hidrología, Meteorología, y Estudios Ambientales-IDEAM; 2011.

82. Dávalos LM, Bejarano AC, Hall MA, Correa HL, Corthals A, Espejo OJ. Forests and drugs: coca-driven deforestation in tropical biodiversity hotspots. Environ Sci Technol. 2011;45:1219-27.

83. Hansen MC, Potapov PV, Moore R, Hancher M, Turubanova SA, Tyukavina A, Thau D, Stehman SV, Goetz SJ, Loveland TR, Kommareddy A, Egorov A, Chini $\mathrm{L}$, Justice CO, Townshend JRG. High-resolution global maps of 21 stcentury forest cover change. Science. 2013;342:850-3.
84. Davis SD, Heywood VH, Herrera-MacBryde O, Villa-Lobos J, Hamilton A. Centres of plant diversity: a guide and strategy for their conservation. Volume 3: the Americas; 1997.

85. Armenteras D, Cabrera E, Rodríguez N, Retana J. National and regional determinants of tropical deforestation in Colombia. Reg Environ Chang. 2013;13:1181-93.

86. Sanchez-Cuervo AM, Aide TM, Clark ML, Etter A. Land cover change in Colombia: surprising forest recovery trends between 2001 and 2010. PLoS One. 2012;7:1-14

87. Negret PJ, Allan J, Braczkowski A, Maron M, Watson JE. Need for conservation planning in postconflict Colombia. Conserv Biol. 2017;31(3): 499-500.

88. González AM, Wilson S, Bayly NJ, Hobson KA. Contrasting the suitability of shade coffee agriculture and native forest as overwinter habitat for Canada warbler (Cardellina canadensis) in the Colombian Andes. Condor. 2020;122: $1-12$.

89. Taylor P, Crewe T, Mackenzie S, Lepage D, Aubry Y, Crysler Z, Finney G, Francis C, Guglielmo C, Hamilton D, Holberton R. The Motus wildlife tracking system: a collaborative research network to enhance the understanding of wildlife movement. Avian Conserv Ecol. 2017;12:1-11.

90. Bégin Marchand, C., F. Gagnon, B. Drolet, J. Ibarzabal, J.A. Tremblay. Fall migration departures and routes from individuals of a northeastern population of Canada warbler (Cardellina canadensis). J Field Ornithol. In Review.

91. BirdLife International (2012). Wilsonia canadensis. The IUCN red list of threatened species 2012. URL: https://doi.org/10.2305/IUCN.UK.2012-1.RLTS. T22721882A39849311.en. Accessed on 21 Feb 2016.

92. Adams EM. Passive acoustics. Biodiversity research institute. Annu Rep. 2014; 18:1-4.

93. Amos EJ. A guide to the birds of Bermuda. Corncrake; 1991.

94. Andrle RF. North American migrants in the sierra de Tuxtla of southern Veracruz, México. Condor. 1966;68:177-84.

95. Bond J. The birds of the West Indies. London: Collins; 1960.

96. Brown AC, Collier N. New bird records from Anguilla and St. Martin. J Caribb Ornithol. 2007:20:50-2

97. Cooke W. Routes of bird migration. Auk. 1905;22:1-11.

98. Craves JA, Hall KR. Notable bird sightings from Cuba, winters 2002 and 2003. J Caribb Ornithol. 2003;16:31-4.

99. Drury WH, Keith JA. Radar studies of songbird migration in coastal New England. Ibis. 1962;104:449-89.

100. Durand AL. Landbirds over the North Atlantic: unpublished records 19611965 and thoughts a decade later. Br Birds. 1972;65:428-42.

101. Gochfeld M. Wintering ranges of migrant warblers of eastern North America. Am Birds. 1979:33:742-5.

102. Mueller AJ, Sears NE. Habitat selection by spring migrants in a Texas coastal woodlot. Bull Tex Ornithol Soc. 1987;20:21-6.

103. Raffaele HA, Wiley J, Garrido OH, Keith A, Raffaele Jl. Birds of the West Indies. Princeton: Princeton University Press; 2010.

\section{Publisher's Note}

Springer Nature remains neutral with regard to jurisdictional claims in published maps and institutional affiliations.

Ready to submit your research? Choose BMC and benefit from:

- fast, convenient online submission

- thorough peer review by experienced researchers in your field

- rapid publication on acceptance

- support for research data, including large and complex data types

- gold Open Access which fosters wider collaboration and increased citations

- maximum visibility for your research: over $100 \mathrm{M}$ website views per year

At $\mathrm{BMC}$, research is always in progress.

Learn more biomedcentral.com/submissions 